Withers, William. Financing Economic Security in the United States. Pp. $\mathrm{x}$, 210. New York: Columbia University Press, 1939. \$2.75.

Mr. Withers has produced a level-headed analysis of the well-nigh insurmountable riddle of social security in the United States and its administration by our more than fifty governments. He has gone exhaustively into the existing data on relief expenditures and has emerged with an evaluation carefully interpreted. The footnotes and the bibliography are of especial value. Attention of the reader is called particularly to the author's able arrangement of his topic into clarifying subdivisions, permitting a lucid assembly of data under the heading to which each detail logically belongs.

The author begins by finding the American public seeking compromise between capitalistic and socialistic principles, a distinction of which the American people in all probability are completely innocent. It is only fair to say, however, that the author's chief use of these categories is to produce such contrast as may make the trends in administration clearer.

Mr. Withers deals gently and generously with the "discretionary" feature of Federal Emergency Relief Administration performance, sticking to statistical and other documentary proof. In his analysis of the capacity of the Nation to pay for social security, he advocates complete revision of our system of taxation, a conclusion with which every student of taxation will readily agree. He finds a substantial margin of ability not tapped in the vast expenditures thus far made for relief; and he assumes that because this margin exists, therefore it ought to be taken up. It seems to the reviewer that not enough weight is given here to the fact that this vast issue is social before it can become economic. Perhaps the public would agree with the author in the end; but to leave this vital aspect of relief unexplored is a serious omission.

Finally, in his discussion of inequalities in local taxing ability in relation to the need for relief, the author advocates thorough equalization through Federal taxation and allocation. He appears to assume that the hard political reality of fortyeight sovereign and independent states, confederated under a federal government of express and limited powers, should be reversed and the Nation henceforth function as a unit under a single government centered at Washington. This conclusion is nowhere expressed, but its consummation is essential to the full logic of the findings.

Mr. Withers' work is couched in plain language, readily understandable, delightfully free from the technical obscurities of the time.

\section{University of Michigan}

ROBERT W. Kelso

Hobbs, Clarence W. Workmen's Compensation Insurance. 2nd Ed. Pp. xviii, 707. New York: McGraw-Hill Book Co., Inc., 1939. $\$ 5.00$.

This book is not a revision of the book by Michelbacher and Nial, bearing the same title, published in 1925. It is a completely new work and a highly remarkable one. From 1925 to 1939 there was an enormous development involving such manifold alterations by laws and practices that even the authors of the first edition hardly would have been in a position to revise the original text without rewriting most of the chapters. The process of permanent changing in regard to workmen's compensation certainly will not stop in the near future. Whether the astounding contrast of regulations in the states will be more unified, remains to be seen.

The author has tried to separate Part I: "The Workmen's Compensation Acts" (pp. 7-312) from Part II: "Workmen's Compensation Insurance" (pp. 313-634). However, it was not possible to separate the material in fact, and therefore perhaps it may be advisable in a third edition to change the arrangements and introduce a more logical distinction. In my opinion, it would be better to begin the book with some chapters out of the second part.

The value of the book goes by far beyond the subject; it contains very valuable and excellent observations in regard to insurance in general. There are books on insurance in general which hardly contain such completeness, for instance in regard 